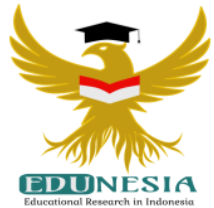

\title{
The Needs Analysis of English in Bina Informatika Vocational High School of Bintaro as A Basis to Design English Teaching Materials
}

\author{
Albiansyah'; Minkhatunnakhriyah ${ }^{2}$ \\ 1,2Magister Pendidikan Bahasa Inggris, Universitas Islam Negeri Syarif Hidayatullah, Indonesia \\ ${ }^{1}$ Corresponding Email: albiaansyah@gmail.com, Phone Number : 0813 xxxx xxxx
}

\author{
Article History: \\ Received: Nov 04, 2020 \\ Revised: Nov 17, 2020 \\ Accepted: Nov 18, 2020 \\ Published: Jan 01, 2021
}

Keywords:

English, Multimedia, Needs Analysis

Kata Kunci:

Analisis Kebutuhan, Inggris, Multimedia.

\section{How to cite: \\ Albiansyah, A., \& Minkhatunnakhriyah, M. (2021). The Needs Analysis of English in Bina Informatika Vocational High School of Bintaro as A Basis to Design English Teaching Materials. Edunesia: Jurnal Ilmiah Pendidikan, 2 (1): 142-152.}

This is an open access article under the CC-BY-NC-ND license (c) $(9)$
Abstract: This study aims to find out the need analysis of teaching and learning English for vocational high school students. It is focused on the students' needs, deficiencies, and desires. To find the source of knowledge to design proper English materials, this study was performed at one of Bina Informatika vocational high school of bintaro, Tangerang Selatan. A series of questionnaires were distributed to multimedia students to analyze their needs, shortcomings, and motivation to learn English for vocational purposes. This survey research using a series of questionnaires covering three measures to determine the needs of students for particular purposes on materials in learning English. There were 41 participants in this study involving the eleventh graders. In figuring out the majority decisions for each item asked, the data were evaluated quantitatively. In investigating the reasons for each result, open-ended interviews were conducted with both the teacher and the students. The result showed that the students were supposed to be able to use English for everyday contact that would be beneficial to their future jobs since fluency in speaking and grammar were burdening them. Therefore, these students need contextual teaching on the delivered topics. In conclusion, the results of this research can be a landmark for creating a package of materials in English learning for the students.

Abstrak: Penelitian ini bertujuan untuk mengetahui analisis kebutuhan pembelajaran bahasa Inggris bagi siswa SMK. Hal ini difokuskan pada kebutuhan, kekurangan, dan keinginan siswa yang menjadi sasaran pembelajaran. Untuk mengetahui sumber pengetahuan dalam merancang materi bahasa Inggris yang tepat, penelitian ini dilakukan di SMK Bina Informatika di Bintaro, Tangerang Selatan. Serangkaian kuesioner dibagikan kepada siswa multimedia untuk menganalisis kebutuhan, kekurangan, dan motivasi belajar bahasa Inggris untuk keperluan vokasional. Penelitian survei ini menggunakan serangkaian kuesioner yang mencakup tiga langkah untuk mengetahui kebutuhan siswa akan tujuan tertentu pada materi dalam pembelajaran bahasa Inggris. Ada 41 peserta dalam penelitian ini yang melibatkan siswa kelas sebelas. Dalam menentukan keputusan mayoritas untuk setiap item yang ditanyakan, data dievaluasi secara kuantitatif. Dalam menyelidiki alasan untuk setiap hasil, wawancara terbuka dilakukan dengan guru dan siswa. Hasil penelitian menunjukkan bahwa siswa diharapkan dapat menggunakan bahasa Inggris untuk percakapan sehari-hari yang akan bermanfaat bagi pekerjaan mereka di masa depan karena kefasihan berbicara dan tata bahasa membebani mereka. Oleh karena itu, para siswa ini membutuhkan pengajaran kontekstual pada topik yang disampaikan. Kesimpulannya, hasil penelitian ini dapat menjadi tonggak pembuatan bahan ajar bahasa Inggris bagi siswa. 


\section{A. Introduction}

Learning English is a prominent thing for vocational high school students to respond to various deficiencies in their future jobs. The role of the teacher is of course very important to facilitate students to acquire adequate English skills. Concerning English students in teaching vocational (English for Specific Purposes), the teachers are asked to develop syllabus and teaching materials from the student's needs based. They should match the realworld professional learner's demands effectively. However, the problem that occurs in Indonesia, especially in South Tangerang, is that the English who teaches in the vocational field has difficulty in designing the teaching syllabus and teaching materials for vocational study programs. Including English teaching at Bina Informatika vocational high school Bintaro, where teachers find it difficult to design teaching materials due to the unavailability of English books specifically for vocational students at the local bookstores while the online books are also not available. Therefore, the analysis of student needs will be an alternative solution to the problem above.

Article 1 (3) of the Government Regulation of Indonesia's Republic No 29 in 1990 at the secondary level of education, Chapter I of the General Provisions, implies that vocational education and training should concentrate on improving the skills of students in specific fields. It is clearly mentioned in Article 3 (2) that vocational education should give priority to the training of vocational high school (VHS) students for entry into the workplace and the development of professional conduct. Also, Article 15 of Act No. 20 in 2003 of Indonesia's Republic on the System of Indonesia National Education declares that vocational high education and training is a program of secondary level in education to prepare students in a particular work. The regulatory statements listed above fully understand that VHS education should equip students with specific skills or, in other words, enable them to have technical skills in a particular field so that they are ready to compete in today's workplace.

As mentioned above, as Widodo (2016) has argued, English subject learning in vocational education, specifically in the secondary level of education, is called as English for Specific Purposes (hereinafter ESP) program. So that, the instructions of English used in ESP teachings must be entirely distinct from the very general English (GE) instructions, serving students with the teaching of all four language skills and emphasizing them equally (Esfandiari, 2015; Rahman, 2015). On the other hand, ESP courses are structured to fulfill the needs of learners and other stakeholders to interact in particular disciplines for work or research purposes (Vogt \& Kantelinen, 2013). They are hardly qualified in using English in a particular context or a specific communicative context in this sense (Liu, Chang, Yang, \& Sun, 2011).

However, the fact that both the school-based curriculum (KTSP) and the 2013's curriculum (K-13) in the VHS and general schools hold similar English learning matters has been disclosed at vocational education's form in Indonesia. More interestingly, both VHS and general school English teachers also use the same course books issued by markets that the material is often inadequate to the needs of VHS students (personal information, 10 August 2020). Moreover, English teachers in both VHS and general schools use the same course books. They also hold the same view that, due to (1) lack of monetary support from the institution, (2) time limit, and (3) insufficiency of understanding in designing or producing teaching materials for a particular area, they had a lack of interest in developing materials that are completely applicable to their needs. 
This research takes place at one of South Tangerang's private VHS, which has a multimedia curriculum that should provide students with the skills to design computer programming, for example, and understand computer and networking components. The English teacher, sadly, appears to use the government's English coursebooks so that the students do not get the required English exposure that is highly needed for their future. In addition, the texts served as inputs for the students in the course books are very general so that they are not contextualized for the multimedia students. Whereas they should experience the texts that are important to their vocational knowledge and skills as they participated in vocational education and place them in unique vocational areas (Widodo, 2016).

The teacher's directions are another explanation of why students do not get the required English learning experience. The directions on teaching English grammar and reading activities that do not include the materials relevant to the vocational field of the students were simply emphasized. This will not deepen their vocational expertise, as such preparation would only discourage them from developing their communicative skills and performing them better. Unsurprisingly, in the field of computer engineering and networks, students do not show adequate knowledge of English. In other words, both of these variables contribute to a mismatch between the academic competence of the vocational graduate and the necessity for the workforce (Amin et al, 2017). It is a must for VHS English teachers to create English learning materials that match their own students' learning needs, clearly expressed in their actual teaching-learning situation, understanding these facts.

Over the past three decades, needs research studies have been undertaken (Widodo, 2016) and several contemporary studies have mushroomed in many different countries on this subject, such as Guiyu \& Yang (2016) conducted a study to analyze the problems faced in China and the current state of the Business English Program while Kayiran \& Bağçeci (2018) also did a current research aims to examine the need for the value educational program for pre-school students. This study was performed in one of the urban cities Kahramanmaraş - with 200 pre-school teachers and Fadel \& Rajab (2017) conducted a study to establish the expectations of the students regarding the value of English skills, the frequency of their use, their abilities to do such skills and their preferences with respect to the English language course and Sabarun (2019) did a research to seek the goals and needs of learning. All in all, these kinds of literature and previous study represent the centrality and unavoidable position of needs analysis.

While the significance and usefulness of the analysis of needs have been recognized all over the earth, it is hardly surprising that only a small number of contemporary studies have been recorded in the contexture of secondary vocational high school or education, especially in this country, Indonesia. To meet this state of the art, the researchers elucidate the needs of the students in the sense of vocational high school through need analysis. This is due to raising awareness of the standard of English teaching in VHS in which the ultimate aim is to increase the academic competence of students to train them as competent employees in today's workplace to have a strong character. Therefore, the researchers are encouraged to anatomize the students' needs for English subject at SMK Bina Informatika Bintaro. Analysis of the students' needs will be the initial focus in designing and developing teaching materials. This research is important to do to help teachers to develop teaching materials and also to assist vocational students in accessing the specific language they need to communicate appropriately according to the demands of their work world. In the future, 
it is hoped that the resulting formulation will be used to compile and develop teaching content and instructional strategies (both in the form of teaching modules, techniques, applications, and others) to assist teachers in the learning process.

\section{B. Method}

This present study was held at SMK Bina Informatika Bintaro. In this survey study, the researchers used a series of questionnaires covering three measures they are students' needs, deficiencies, and desires to determine the needs of students for particular purposes in the knowledge of English materials. Mayang, et. al (2019) note that questionnaires are fairly simple to execute so that methods often function in the needs of analysis. Each dominant answer is cross-checked in English to verify the results of the questionnaire. This survey research contextualized for a private school in South Tangerang students of Multimedia. As the participants, 41 students chosen by random sampling. The questions in the interview are considered open-ended interviews. Their responses to each item's choices have been changed to a percentage to look for which option is protruding along with the other options. In designing English teaching materials for the students, the dominant choices were then considered as the most informative feedback to be considered. The formula can be portrayed:

$$
\begin{aligned}
& \text { Percentage } \\
& \frac{x}{n} \times 100=P
\end{aligned}
$$

Where:

$x=$ given quantity

$n=$ total amount

$P=$ percentage of quantity, compared to total

\section{Result and Discussion}

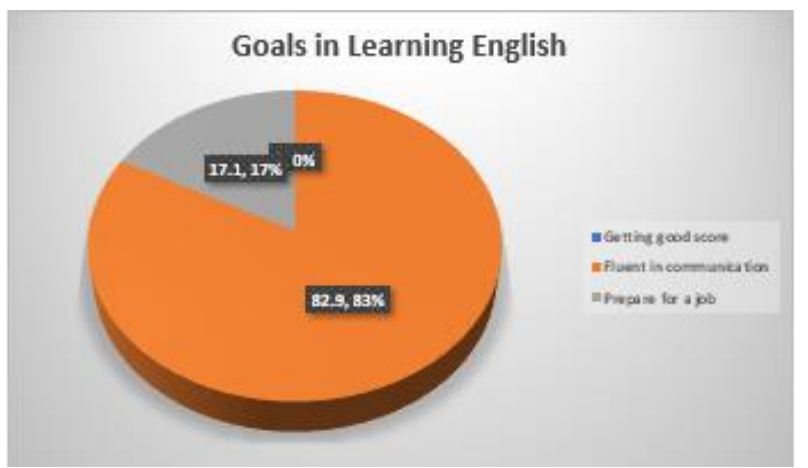

Figure 1. The Goals in Learning English

As is seen in figure 1, it reveals that $82.9 \%$ of the amount of selection is given to students studying English to make them fluent in both spoken and written language. It demonstrates if the most important materials to be included should continue to be language skills. On the other hand, they choose to prepare job opportunities as a primary reason for learning English, 17.1 percent of them learn English, and interestingly, only 0 percent of them choose to achieve a good final score in English subject. 


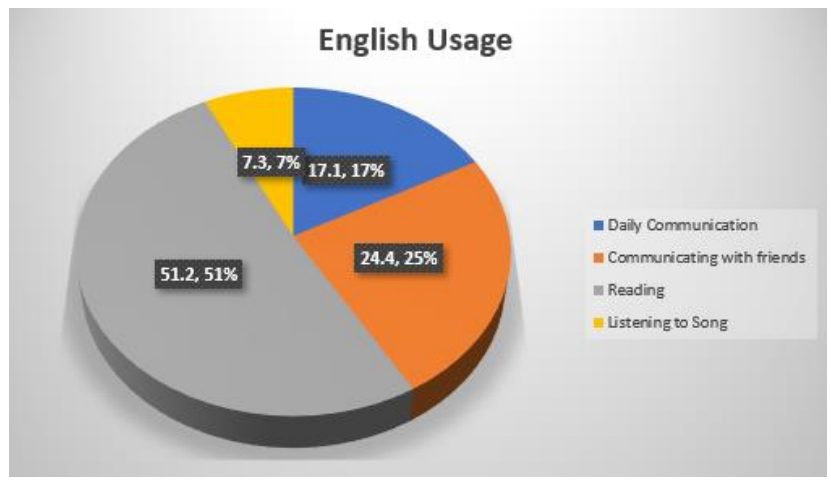

Figure 2. The English Usage

Figure 2 shows that the current options of the students are reflected in what English is used to $51.2 \%$ of all choices are aimed at reading materials in English text, followed by $24.4 \%$ using English for interacting with friends using English. In comparison, $17.1 \%$ of choices are targeted at using English as a medium for daily life communication, and only $7.3 \%$ of overall choices are addressed to listening to English songs. It concludes that most students do not listen to English songs and most of them use English to read English reading materials.

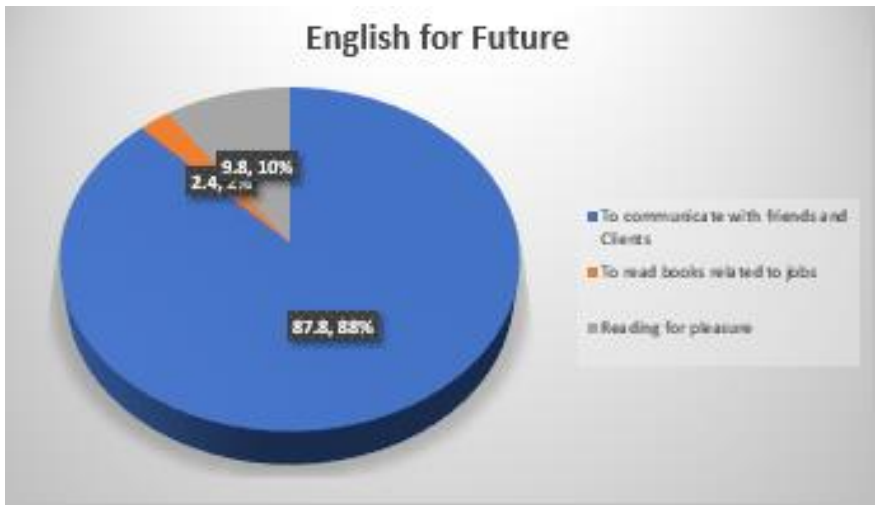

Figure 3. The Perception of Students in Using English in the Future

Figure 3 shows the student's opinion at their potency use in English, which suggests the understanding of its potential importance. This figure reveals that more than half of the collection is targeted at engaging with peers, bosses, and/or clients $(87.8 \%)$. This means that half of the students think it's really important to master English to help them get their future jobs. however, $9.8 \%$ percent of the number of options are targeted at reading for pleasure. In the last place, $2.4 \%$ reading employment-related literature. 


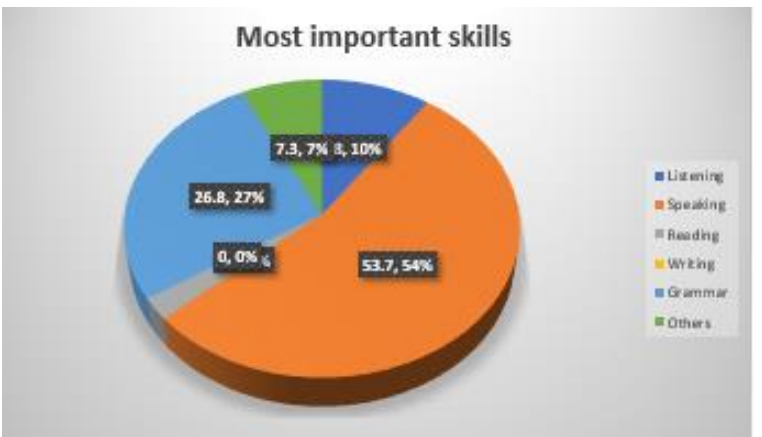

Figure 4. The Options of Students on the Most Important Elements in English

Figure 4 represents the percentage of priority for students in mastering language skills and components. Speaking ls are shown to have the highest proportion $(53.7 \%)$. It should be noted that learning materials should include speaking exercises to fulfill the requirements of the students. The second highest percentage is grammar, which is considered crucial for many learners to learn. With $26.8 \%$ and $7.3 \%$ grammar, the following component is listening. While $7.3 \%$ of others were selected, reading was $2.4 \%$. The number of percentages of one ability does not vastly dominate other abilities. This illustrates that there is no talent that is absolute to be concentrated on in contrast with other abilities. It sums up that speaking abilities and other components might be well thought of equivalent in the place of partial and integrated.

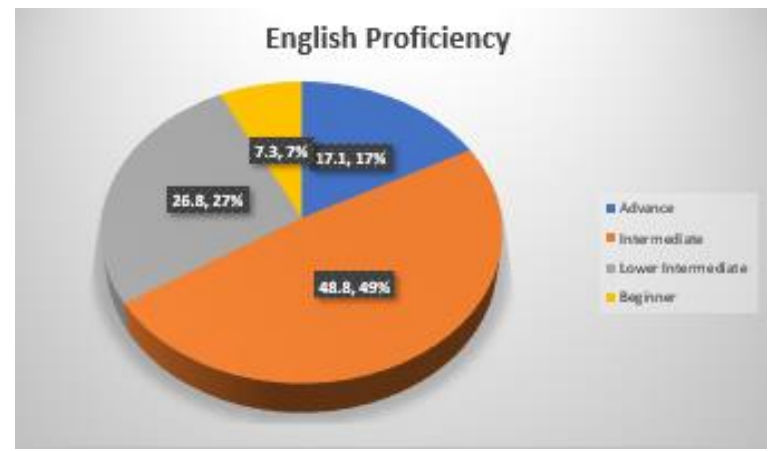

Figure 5. The Students' Self-Evaluation toward their Proficiency level of English

Figure 5 shows the percentage of English proficiency levels of students based on their self-assessment. They have been given four stratified levels to choose what level they belong to subjectively. It was discovered in English that $48.8 \%$ of them assume that they are intermediate. This suggests that, while not yet fluent, they believe they can communicate both orally and in written form. On the other hand, 26.8 of them believe they belong to the lower intermediate in English. This means that they think they can understand what people are saying or what they are reading, but they cannot respond properly. $7.3 \%$ of students think that they are at the level of beginners, which suggests that they lack English exposure. $17.1 \%$ of students believe that they are at an advanced stage, which means that they can engage fluently with any sense. 


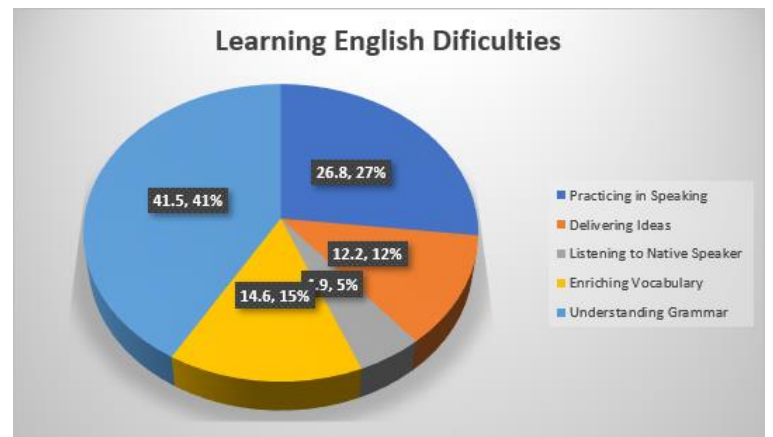

Figure 6. The Students' Difficulties in Learning English

From figure 6, it is got that some of the problem students got during the learning process is $41.5 \%$ knowing and employing grammar, $26.8 \%$ communication practice, $14.6 \%$ developing vocabulary, $12.2 \%$ delivering ideas, $4.9 \%$ listening to native speakers.

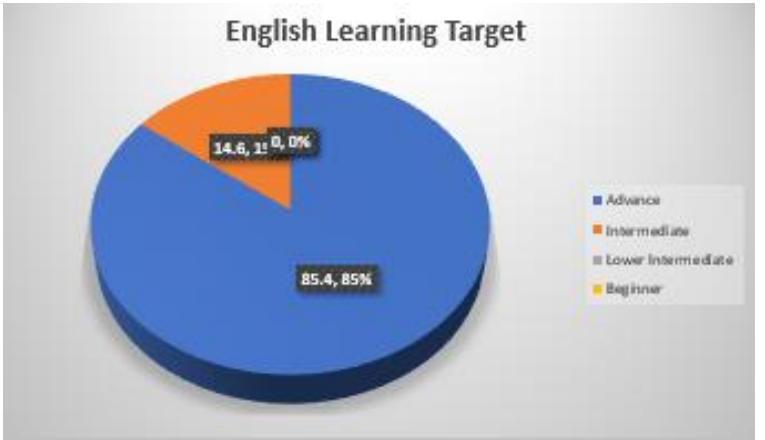

Figure 7. Targets of Students in Their Level of English Proficiency

The students' target to achieve after learning English as can be seen in figure 7, they want to be able to talk fluently, it has been discovered that $84.5 \%$ of students expect to be advanced learners. In English, 14.6\% of them hope they want to hit the intermediate stage. No students are hoping to hit a lower intermediate and beginner level.

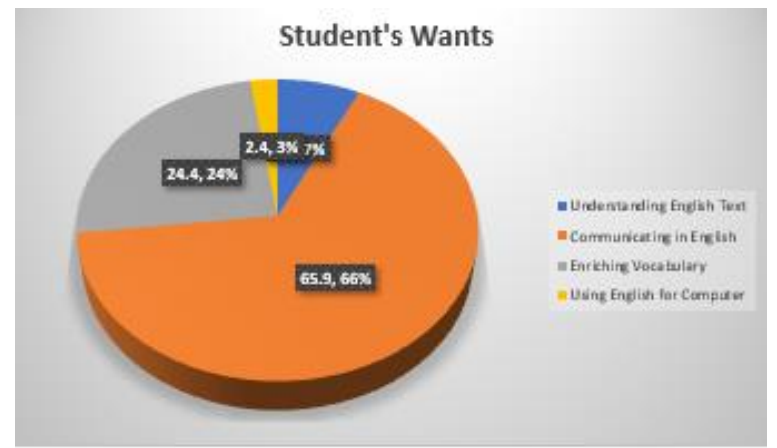

Figure 8. The Students' Wants

Figure 8 shows in learning English, it reveals the desires of students. The figure demonstrates, in particular, what English matters they expect in learning on their English module. The responses to this aspect are different. $65.9 \%$ of learners desire to learn materials that enlarge their ability to communicate. The option of $24.4 \%$ is aimed at learning English vocabulary. $7.3 \%$ of the students prefer resources that enhance their understanding of 
reading, and in certain sessions, $2.4 \%$ of the students choose to learn English for the computer.

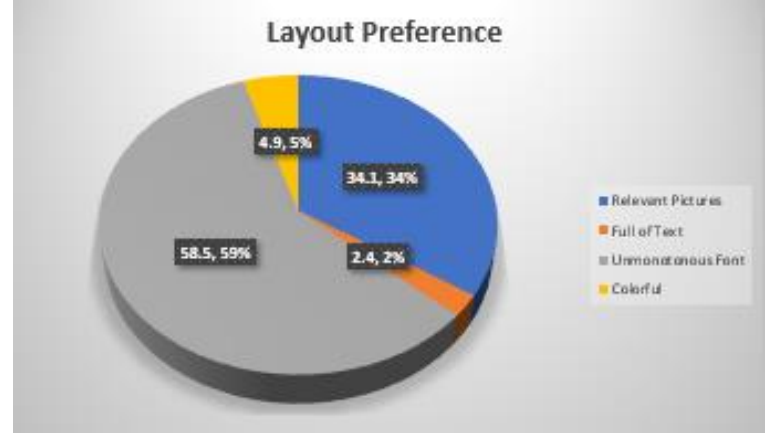

Figure 9. Preferred Layout

The students were also asked about their favorite module layout. Figure 9. It reveals that $58.8 \%$ of the choices were addressed to a non-monotonous font layout and $34.1 \%$ to layout with appropriate images. On the other hand, $4.9 \%$ of the choice is to a vibrant layout, and $2.4 \%$ of the options are full-text layout.

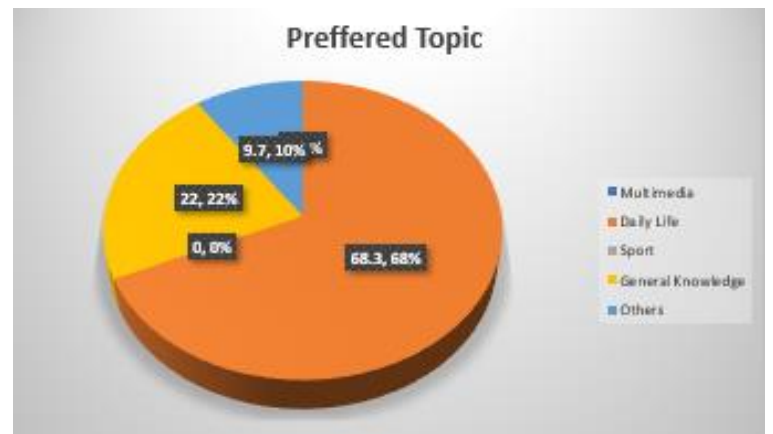

Figure 10. The Students' Preferred Topic

The students were also asked what subject they would like to learn more about. It is about general knowledge, multimedia, sports, topics of everyday life, and other materials. figure 10 indicates that $68.3 \%$ of the options are everyday life subjects followed by general knowledge for $22 \%$. Then, $9.8 \%$ asked for everyday life subjects, and 9.6 percent wanted to learn about other topics. Nobody prefers meaningless topics, such as athletics.

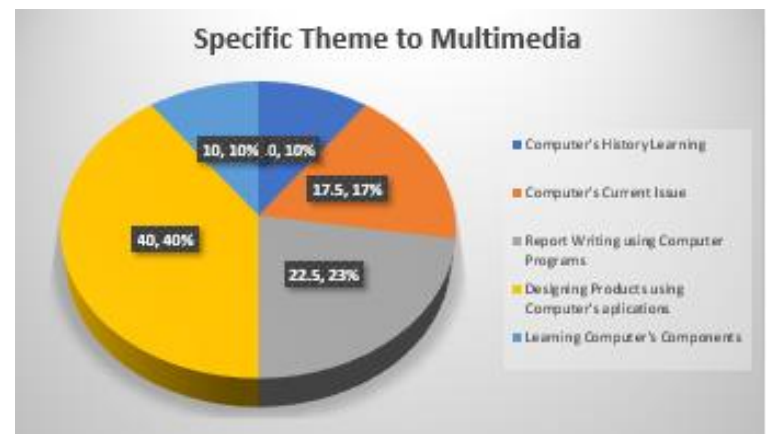

Figure 11. The Students' Preference to Themes of English for Multimedia 
The last thing presented to the students is what computer-related topics they want to study since the major is related to the computer which is multimedia students. The percentage for this option is $40 \% .22 .5 \%$ of the students asked to learn how to write report writing by using a computer's application. $17.5 \%$ of the students asked to learn the learn about describing computer parts, debating about computer problems, equivalent percentages $(10 \%)$ of the choices requested to learn about the history of computer engineering and computer components.

\section{The Student's Necessities}

Four things were given to finalize the needs of the students in learning English. They are (1) the objective(s) of learning English, (2) the sense in which English is used, (3) English usage is very beneficial for their future, and (4) the skills or elements in English that they think which is relevant. It's shown in figure $1,82.9 \%$ is targeted at becoming fluent in spoken and written communication. It indicates that they appreciate the exigence of learning well the skills of the language. Becoming fluent in verbal speech meaning that, as the teacher proposed, they need to be excellent at listening and speaking. To have fluent written communication, on the other hand, means that they must juggle reading and writing skills. Therefore, the acquisition of skills through learning experiences is necessary for students to experience them. This is in line with Nishanthi (2018) that students believe that fluency or mastery of the English language is obligatory to excel in the era of globalization.

Figure 2 shows which scenario they mainly use English in. This is to assess their attitude towards using English and their usual activities. It is found because when Reading English materials, they mainly use English with 51.2\% followed by Communicating with friends with $24.4 \%$. It demonstrates that in receptive skills, the learners are dominant. This result shows that reading English materials is eligible and that speaking methods should be taken into account as they said they requested.

The third aspect focuses on to what degree in the future they will find English essential to learn. twenty-four percent of students agreed that it is appropriate to connect with friends, supervisors, and clients, Nishanthi (2018) states that it is known that A significant role is played by English in the world today to support people in their job and daily life. To get this experience, learners need to get proper communication learning experience at a higher level, the equal level, and the lower ones.

Figure 4, reflects the language skills' proportion and components that students desire. Students have been shown to give importance to speaking abilities in the first order, followed by grammar abilities at the second and listening in the third one. One student agrees that speaking ability is the secret to good communication. This result seems important because they are going to be involved in the working field that needs to survive those skills. Therefore, to be translated to learning activities in the module, the top three skills must be of great attention without ignoring writing skills in the fourth position. By following Nasution (2016), speaking capacity plays a prominent part in today's world.

\section{The Students' Lacks}

The shortcomings of the learners are expressed in which figuring out about to what extent the learners feel they are fluent in the spoken language of English, and their obstacles in studying English. figure 5 indicates 48.8 percent of the students evaluated themselves as an intermediary in English. Although $26.8 \%$ of them assume that they belong to the lower 
intermediate. The teacher accepted that, based on the score recorded by the teacher, most of the students belong to the intermediate level. This implies that they need adjustment so that they can belong to a higher rank. Effective learning strategies must be in place to gain the goal, as Kunasaraphan (2015) states that the strategy of learning makes students strengthen the student's obstacle to target language. Students, on the other hand, find it difficult to understand and using grammar (41.5\%). After $26.8 \%$ of difficulties in communication practice, and $12.6 \%$ of them find it challenging in delivering ideas as shown by figure 6 . It is concluded that in designing the materials, reading activities must be taken into account. Consequently, texts are required.

\section{The Students' Wants}

During and after learning English, the students were also asked about their interests. After learning English, their goal is to progress to the level of English proficiency (85.4 percent). As can be seen in figure 7 , it is reinforced by the findings that some students expect high expectations of the teaching process so that their English skills can be enhanced. In addition, after learning the module, figure 4 demonstrates the skills that students want to have. 53.7 percent of them have been found to want to be able to communicate. This result is similar to Hidayati's and Haryati's (2018) result that 53 learners responded to their research findings that most of the students chose communication fluency.

\section{Conclusion}

Analysis functions are required to provide fundamental inputs to the production of English materials aimed at specific purposes. To gain useful information from the target to improve learning results, this was compulsory for English practitioners to undertake this survey analysis. Overall, it can be concluded that students need to interact in English in both everyday communication and technical fields, speaking skills to be more concerned, computer-related content, colorful and interesting image layout. All of the points listed are useful for the design of the English teaching materials for vocational high school students in multimedia. This result is known to be situational, so it is suggested that English teachers teaching in the school perform the same study of needs to expose the real needs of their students in learning English.

\section{References}

Amin, M., Arifuddin, \& Nurahmadi. (2017). Pragmatic Competence and Learning Needs of English for Students of Tourism Vocational Schools in Nusa Tenggara Barat Province. International Journal of Educational Policy Research and Review, 4(4), 53-61. https://doi.org/10.15739/IJEPRR.17.007

Depdiknas .2003. Undang-undang RI No.20 tahun 2003. Sistem Pendidikan Nasional.

Esfandiari, R. (2015). An Investigation into ESAP Needs of Iranian BA Students of Law. The Journal of Teaching Langauage Skills (JTLS), 7(3), 29-59.

Fadel, S., \& Rajab, H. (2017). Investigating the English Language Needs of the Female Students at the Faculty of Computing and Information Technology at King Abdulaziz University in Saudi Arabia. English Language Teaching, 10(6), 69-82. 
Guiyu, D., \& Yang, L. (2016). An Empirical Study on Business English Teaching and Development in China - A Needs Analysis Approach. Higher Education Studies, 6(2), 142-153. https:// doi.org/10.5539/hes.v6n2p142

Hidayati, D. N,. \& Haryati, S. (2018). Target and Learning Needs in English for Midwifery Students. LEKSEMA: Jurnal Bahasa dan Sastra. 3(1). 71-80.

Kayiran, D., \& Bağçeci, B. (2018). Needs Analysis on Values Education Programme for Preschool Students. Journal of Education and Training Studies, 6(10), 69-73. https://doi.org/10.11114/jets.v6i10.3538

Kunasaraphana, K. (2015). English Learning Strategy and Proficiency Level of the First Year Students. Procedia - Social and Behavioral Sciences. Vol. 197. 1853-1858,

Liu, J., Chang, Y., Yang, F., \& Sun, Y. (2011). Is What I Need What I Want? Reconceptualizing College Students Needs in English Courses for General \& Specific or Academic Purpose. Journal of English for Academic Purposes, 10(4)., 271-280. https://.doi.org/10.1016/j.jeap.2011.09.002

Mayang, A., Nurkamto, J., \& Drajati, N. A. (2019). The Needs Analysis of Senior High School Students' Reading Competence in National Examination: Students' Perspective. Eternal: English, Teaching, Learning, and Research Journal. 5(1). 130- 142.

Nasution, S. S. (2016). Model United Nations: Its Effectiveness to Teach Speaking Viewed from the Students' Learning Motivation. Unpublished Thesis. Universitas Sebelas Maret. Surakarta

Nishanthi, R. (2018). The Importance of Learning English in Today World. International Journal of Trend in Scientific Research and Development. 3(1). 871-876.

Peraturan Pemerintah Republik Indonesia. 1990. PP Nomor 29 Tahun 1990 tentang Pendidikan Menengah.

Sabarun. (2019). Needs Analysis on Developing EFL Paragraph Writing Materials at Kalimantan L2 learners. English Language Teaching, 12(1), 186-193. https://doi.org/10.5539/elt.v12n1p186

Vogt, K., \& Kantelinen, R. (2013). Vocationally Oriented Language Learning Revisited. ELT Journal, 67(1), 62-69. https:// doi.org/10.1093/elt/ccs049

Widodo, H. P. (2016). Teaching English for Specific Purposes (ESP): English for Vocational Purposes (EVP). In W. A. Renandya \& H. P. Widodo (Eds.), English Language Teaching Today: Linking Theory and Practice (pp. 277-291). Springer International Publishing. https://doi.org/10.1007/978-3-319-38834-2_19 